1 Citizenship after Orientalism

2

3

4

5

6

7

8

9

10

11

12

13

14

15

16

17

18

19

20

21

22

23

24

25

26

27

28

29

30

31

32

33

34

35

36

37

38

39

40

41

42

43

44

45

46

47

48

49

50

51 
Palgrave Studies in Citizenship Transitions

Series editors

Michele Michiletti is Lars Hierta Chair of Political Science at Stockholm University, Sweden. Ludvig Beckman is Professor of Political Science, Stockholm University, Sweden. David Owen is Professor of Social and Political Philosophy, University of Southampton, UK.

The Editorial Board: Keith Banting (Queen's University, Canada), Rainer Baubock (European University Institute, Italy), Russell Dalton (University of California at Irving, USA), Avigail Eisenberg (University of Victoria, Canada), Nancy Fraser (The New School for Social Research, USA), David Jacobson (University of South Florida, USA) and Ariadne Vromen (The University of Sydney, Australia).

This series focuses on citizenship transitions encompassing contemporary transformations of citizenship as institution, status, and practice as well as normative and explanatory analysis of these transformations and their cultural, social, economic, and political implications. The series bridges theoretical and empirical debates on democracy, transnationalism, and citizenship that have been too insulated from each other. It takes citizenship transitions as its starting point and studies the status, role, and function of citizenship within contemporary democratic systems and multi-layered governance structures beyond the state. It aims to add a broader array of critical, conceptual, normative, and empirical perspectives on the borders, territories, and political agents of citizenship. It scrutinizes the possibilities and challenges of citizenship in light of present broad processes of political fragmentation and pluralization and the ways emerging ideals and expectations of citizenship are inspired by new social, political, and environmental movements. Its cross-disciplinary approach intends to capture the transitions of citizenship from an apparently simple relation between the state and its citizens into a cluster of complex responsibility claims and practices that raise questions concerning citizenship borders and obligations, the public-private scope of citizenship, and even how political actors attempt to and in fact avoid citizenship.

Titles in the series include:

Ludvig Beckman and Eva Erman (editors)

TERRITORIES OF CITIZENSHIP

Costica Dumbrava

NATIONALITY, CITIZENSHIP AND ETHNO-CULTURAL BELONGING

Preferential Membership Policies in Europe

Karin Svedberg Helgesson and Ulrika Mörth (editors)

THE POLITICAL ROLE OF CORPORATE CITIZENS

An Interdisciplinary Approach

Simon McMahon

IMMIGRATION AND CITIZENSHIP IN AN ENLARGED EUROPEAN UNION

The Political Dynamics of Intra-EU Mobility 
2

3

4

5

6

11

12

13

14

15

16

17

18

19

20

21

22

23

24

25

26

27

28

29

30

31

32

33

34

35

36

37

38

39

40

41

42

43

44

45

46

47

48

49

50

51

Palgrave Studies In Citizenship Transitions series

Series Standing Order ISBN 978-1-137-33137-3

You can receive future titles in this series as they are published by placing a standing order. Please contact your bookseller or, in case of difficulty, write to us at the address below with your name and address, the title of the series and the ISBNs quoted above.

Customer Services Department, Macmillan Distribution Ltd, Houndmills, Basingstoke, Hampshire RG21 6XS, England 
1

2

3

4

5

6

7

8

9

10

11

12

13

14

15

16

17

18

19

20

21

22

23

24

25

26

27

28

29

30

31

32

33

34

35

36

37

38

39

40

41

42

43

44

45

46

47

48

49

50

51 


\section{Citizenship after Orientalism Transforming Political Theory \\ Edited by \\ Engin Isin \\ Professor of Citizenship, Open University, UK}

48

49

50

51

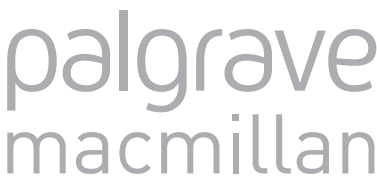


Introduction, conclusion, selection and editorial matter (c) Engin Isin 2015 Individual chapters (c) Respective authors 2015

All rights reserved. No reproduction, copy or transmission of this publication may be made without written permission.

No portion of this publication may be reproduced, copied or transmitted save with written permission or in accordance with the provisions of the Copyright, Designs and Patents Act 1988, or under the terms of any licence permitting limited copying issued by the Copyright Licensing Agency, Saffron House, 6-10 Kirby Street, London EC1N 8TS.

Any person who does any unauthorized act in relation to this publication may be liable to criminal prosecution and civil claims for damages.

The author(s) has/have asserted his/her/their right(s) to be identified as the author(s) of this work in accordance with the Copyright, Designs and Patents Act 1988.

First published 2015 by

PALGRAVE MACMILLAN

Palgrave Macmillan in the UK is an imprint of Macmillan Publishers Limited, registered in England, company number 785998, of Houndmills, Basingstoke, Hampshire RG21 6XS.

Palgrave Macmillan in the US is a division of St Martin's Press LLC, 175 Fifth Avenue, New York, NY 10010.

Palgrave Macmillan is the global academic imprint of the above companies and has companies and representatives throughout the world.

Palgrave ${ }^{\circledR}$ and Macmillan ${ }^{\circledR}$ are registered trademarks in the United States, the United Kingdom, Europe and other countries.

ISBN: 978-1-137-47949-5

This book is printed on paper suitable for recycling and made from fully managed and sustained forest sources. Logging, pulping and manufacturing processes are expected to conform to the environmental regulations of the country of origin.

A catalogue record for this book is available from the British Library.

A catalog record for this book is available from the Library of Congress. 


\title{
8 \\ Multicultural Society Must Be Defended?
}

\author{
Zaki Nahaboo
}

\begin{abstract}
This chapter investigates how orientalist citizenship is reinvented through attempts to define and defend multicultural society in Britain. I begin by describing how the normalizing function of 'state racism' charted in Michel Foucault's Society Must Be Defended has been partially recast through the 'postracial', 'multiculturalist', and 'multiculture' conceptions of multicultural society. In doing so, this chapter helps us to identify the parameters through which new expressions of orientalist citizenship emerge to sustain contemporary state racism. This is exemplified in the figures of citizenship that manifest through an ethnic minority wing of the United Kingdom Independence Party, calls in the British media for intercultural dialogue, and the Stop the War Coalition's response to the War on Terror in the 2000s. Each captures how attempts at subverting identitarian life scripts, dichotomous subject positions, and essentialist identities become a means of reinventing orientalist citizenship. I conclude that the co-option of anti-essentialist challenges to orientalist citizenship facilitates a new imperative to state racism: 'multicultural society must be defended'.
\end{abstract}

\section{Introduction}

From the mid-1960s onwards, Britain became increasingly characterized as a multicultural society. ${ }^{1}$ Yet its referent escapes consensus. The phrase 'multicultural society' is used to denote a political community marked by diversity in faith, 'race', nationality, attire, music, cuisine, language, customs, values, and citizenship status. What politicians and media commentators across the mainstream political spectrum tacitly agree upon is the irreversibility of multicultural society. ${ }^{2}$ As Stuart Hall observes, contemporary Britain 'can [still] have purges...it can enforce assimilation but it can't go back to being stable and steady on its own mono-cultural foundations'.$^{3}$ This chapter explores the governmental effects of the naturalization and normalization of multicultural society upon orientalist citizenship. 
The figure of the citizen is dominantly understood as having a Western genesis. Engin Isin notes that in the 'occidental tradition' it is considered a sovereign figure 'capable of judgment and being judged, transcending his (and much later her) tribal, kinship, and other primordial loyalties and belongingness'. ${ }^{4}$ The orientalist citizen emerges when this figure is co-constituted with, and hierarchically opposed to, 'oriental' others who are said to lack these faculties. ${ }^{5}$ This chapter demonstrates how 'state racism', as outlined by Michel Foucault in Society Must Be Defended, continues through 'post-racial', multiculturalist, and 'multiculture' conceptions of multicultural society. It investigates how certain attempts to define and defend multicultural society operate as a prism through which otherwise antithetical racist and anti-racist discourses become combined and refracted to facilitate novel expressions of orientalist citizenship. This can be illustrated through the emergence of three figures: 'just-in-time' citizens, intercultural citizens, and anti-civilizational citizens.

To legitimate its anti-immigration policies, the 2013 and 2014 campaigning by the United Kingdom Independence Party (UKIP) emphasized its multiracial membership. While UKIP's hostility towards multicultural society is now unequivocally embraced, I draw attention to the brief campaigning by UKIP's ethnic minorities to reveal a moment where 'just-in-time' citizens mobilize a post-racial conception of society. This is shown to facilitate the rejection of recent immigrants beyond traditional terms of a national 'us' and a racialized 'them'.

The orientalist possibilities of intercultural citizens are revealed through Make Bradford British. The Channel 4 'documentary', broadcasted in 2012, reveals how critiques of essentializing definitions of multicultural citizenship can be disassociated from a progressive anti-racist trajectory. The programme exemplifies how state racism can be reconstituted even through challenges to dichotomous notions of an 'us' and 'them'. Finally, the Stop the War Coalition's (StWC) deployment of anti-civilizational citizens is analysed. It illustrates how the deconstruction of civilizational hierarchies through multiculture can unintentionally realize state racism through anti-civilizational citizens' normalization of secular protest.

These three figures of the citizen are politically incongruent. Yet they respectively capture how attempts at subverting identitarian life scripts, dichotomous subject positions, and essentialist identities have become a means of constituting orientalist citizenship. This chapter concludes that anti-essentialist possibilities to overcome orientalist citizenship have partially been co-opted and foreclosed through state racism's new imperative: 'multicultural society must be defended'.

\section{Towards an Account of State Racism in Multicultural Society}

From the seventeenth century onwards, populations in Western Europe statistically emerged in tandem with governmental concerns about how to regulate 
health, movement, productivity, and the relationship between resources and inhabitants. ${ }^{6}$ Populations became perceived as a natural phenomenon that has its own regularities and constitution, thereby resituating governmental focus from the 'juridical-political' to objects of management. ${ }^{7}$ Creating populations as natural phenomena to be steered, vitiated, and made productive meant that the scale of governmental address shifted onto facilitating life itself. ${ }^{8}$ Foucault argued that during the nineteenth century this expression of 'biopolitics' became interwoven with earlier disciplinary strategies of normalizing and regulating society. ${ }^{9}$ One of the lynchpins that enabled biopolitics to discriminate between healthy and unhealthy populations was state racism. This posited that 'society must be defended' against other 'races', now considered as an intrinsic element of society that must be expelled. ${ }^{10}$ Crucially, every act of expulsion was made correlative to the health and hygiene of a population deemed rightful and authentic. ${ }^{11}$ In other words, state racism introduced a socially diffused economy of life and death that can organize, legitimate, and sustain the traditional function of the sovereign's right to kill.

If state racism gains its most virulent and explicit expression through Nazism and certain variants of socialism, as Foucault described, this does not mean that state racism always relies solely upon biological or culturalist notions of race and class for its sustenance. ${ }^{12}$ One of the central (if not always present) mechanisms of contemporary state racism is orientalist citizenship. This is evident through the War on Terror as principles of democracy and citizenship have begun to gain value through overseas wars on so-called fundamentalists. ${ }^{13}$ Orientalist citizenship is also present when Muslims become classed as 'anti-citizens' and defined against a liberal secular population. ${ }^{14}$ Both instances reveal how orientalist citizenship constitutes an 'us' and 'them' as a zero-sum political relation. In addition, these examples illustrate orientalist citizenship's tacit role in shaping the 'capacities' and pathways for defining what counts as legitimate expressions of political subjectivity. ${ }^{15}$

What occurs when expressions of orientalist citizenship become recast in terms of a nationally framed multicultural society? In this section, the labels 'post-racial', 'multiculturalist', and 'multiculture' are used to highlight separate points of departure for how multicultural society has been defined and defended. By providing an overview of each conception, the terrain through which transformed expressions of orientalist citizenship can be identified, along with their function for revitalizing state racism.

Multicultural society is sometimes used as a symbolic marker for a post-racial society. This conception utilizes the signifier of the multicultural to claim that racial differentiation is either being overcome or cannot be discussed without reaffirming its existence. The post-racial conception of multicultural society has enabled racism to thrive under the guise of cultural incommensurability and 'too much diversity'.$^{16}$ It is against this backdrop that statistically assessing whether racialized Muslims 'feel' loyalty to Britain becomes a gauge of inclusive citizenship. ${ }^{17}$ After the 2005 bombings in London, the growth in polls by think-tanks and media outlets can be interpreted as one of the sites which 
made allegiance a central variable for constructing and discerning the health of multicultural society. ${ }^{18}$ This enables state racism to operate in a bifurcated manner. Through a post-racial conception of defining and defending multicultural society, Muslims can be written into the national narrative as Britons who mostly belong. Yet the commonplace phrase 'most Muslims are not extremists' is qualified by Muslims being made answerable (although not responsible) for extremism. ${ }^{19}$ Subsequently a 'good' and 'bad' Muslim is categorized to deflect the racializing process that ultimately structures Muslims as problem subjects. ${ }^{20}$

The multiculturalist conception of multicultural society as an object of defence can be characterized through its two dominant possibilities. On the one hand, the valourization of (or aspiration for) a tolerant multicultural society that is free from racism becomes testimony to an inclusive national imaginary. ${ }^{21}$ On the other hand, defending multicultural society in these terms has also fuelled the War on Terror through creating orientalized subjects as those who constitutively exceed the parameters of tolerance. ${ }^{22}$ These two possibilities of the multiculturalist conception do not exist in a dichotomous relation. As Alana Lentin and Gavin Titley argue, the division of populations according to 'good' and 'bad' forms of diversity shares the same concern around setting the 'acceptable limits of adversarial politics' ${ }^{23}$

Positing multicultural society as a situation or 'experience' of multiculture illustrates a third conception of multicultural society. ${ }^{24}$ According to this conception, multicultural society is not defined by its supposed communities but by how it operates as a floating signifier of unsettled differences prior to statist attempts that 'manage the problems of diversity and multiplicity'. ${ }^{25}$ Identities and racism do not cease to exist. The setting of identities, both in racist terms, and banal presence with uncertain boundaries, is taken as a 'multiculturalism of fact'. Multicultural society becomes viewed as a terrain where cultural racisms and the ethnic transformation of notions of belonging can coexist without conflict. ${ }^{26}$ More specifically, adapting William Connolly's characterization of identity politics, attempts to 'pluralize' identities become symbiotic with attempts to 'fundamentalize' identities. ${ }^{27}$ This does not always denote a political deadlock. Ash Amin, for instance, highlights how instances of multiculture which are orientated towards shared projects (not necessarily anti-racism) can indirectly untether culture from its presumed racialized bodies and undo racism. ${ }^{28}$

The post-racial and multiculturalist conceptions are points of departure for defining and defending multicultural society which necessarily involve a formula akin to 'us + others $=$ multicultural we $\neq$ them' ${ }^{29}$ In other words, the post-racial and multiculturalist conceptions can facilitate a virtuous and legitimate population as multicultural. This population is simultaneously on the cusp of being divided into a 'them' by those who still retain their status as a demographic 'us'. In contrast, it would appear that the multiculture conception problematizes (rather than promulgates) a conjoined definition and defence of multicultural society. The anti-essentialist possibilities of 'multiculture' appear intrinsically less susceptible to state racism. 
The post-racial, multiculturalist, and multiculture conceptions illustrate an unsettled dynamic of creating, governing, and contesting population differentiation. It is against this backdrop that state racism in Britain is beginning to adopt more nuanced dividing practices through new expressions of orientalist citizenship, which depend upon blurring these three conceptions. The remainder of this chapter illustrates this through attempts by just-intime citizens, intercultural citizens, and anti-civilizational citizens at defining and defending multicultural society.

\section{Just-in-Time Citizens: UKIP's Minorities}

The biological underpinnings of nineteenth-century state racism contrasted with an earlier 'race struggle'.$^{30}$ This made race (understood as linguistic, cultural, national, or religious bonds) a counter-hegemonic discourse to undermine the rightfulness and virtue bestowed upon the dominant. Race struggle involved formulating a 'counterhistory' that undermined the tethering of a monumentalized history to sovereignty as a means of establishing the rightfulness and legality of rulers. ${ }^{31}$ Put differently, just as state racism introduced historical narrative as a political device that legitimized a segmented population as the rightful inhabitants, race struggle drew attention to subjugated histories to constitute the marginalized as rights claimants. ${ }^{32}$

In 2000, a group of esteemed scholars, politicians, journalists, and raceequality experts were assembled to produce a report on the inequalities and challenges facing multicultural Britain. The ensuing report, The Commission on Multi-Ethnic Britain: The Parekh Report, can be viewed as one fleeting instance of race struggle. According to that report, creating a multicultural society free from racialized hierarchies necessitates rewriting national history and pluralizing ethnic representation in public life. The report stated that an obstacle to this goal was the 'unspoken racial connotations' that mired British identity. ${ }^{33}$ The commissioners considered that this image of Britishness was suffused by traces of imperialism, which legitimated the position of the dominant ethnicities in Britain. Mounting a critique of imperialist amnesia through educational and media spheres would, in their view, require incorporating postcolonial history into the national narrative. ${ }^{34}$

This project of challenging the authorized narratives of Britain's history and undifferentiated rights regime depended upon reconceptualizing Britain as a 'community of communities and a community of citizens' ${ }^{35}$ The usage of citizens in this phrase denotes more than the regulative function civil rights discourse serves in communitarian visions of multicultural society. When taken in the context of the report's postcolonial critique, the citizen is transformed from its liberal non-racial positioning into what might be termed just-in-time citizens.

By this term I mean citizens who have firstly constituted themselves as having caught up with the national imaginary, and only through doing so 
position themselves as indistinguishable in status from the historically dominant non-racialized population. They are also subjects produced to inject the national narrative, occupational culture, and education with differences that both reflect and instill the ever-changing requirements for how a harmonious multicultural society is envisaged.

From the time of its publication, the media largely ignored the recommendations of the authors and instead wrongly perceived it as denouncing Britishness. ${ }^{36}$ Over a decade has passed since postcolonial critique was rejected as a guide for British multicultural society to become non-racial. Just-in-time citizens failed to emerge as a postcolonial intervention for shaping anti-racist notions of belonging. They instead surfaced through what Paul Gilroy notes as the niche market of 'diversity and equality consultants': an outsourcing of anti-racism into the equal opportunity agendas of public bodies. ${ }^{37}$ As the dominant image of the just-in-time citizen shifts from a subject who introduces difference to an agent of diversity management, this figure gained a new trajectory that further eroded its anti-racist potential. This can be explored through the United Kingdom Independence Party (UKIP).

Since its founding in 1993, UKIP has mostly remained on the margins of mainstream politics. The anti-immigrant party's major breakthrough came in 2014 when it beat both Labour and the Conservatives in the European elections. ${ }^{38}$ What distinguishes it from other far-right groups is that UKIP supposedly runs on a non-racist platform of addressing nationally ungovernable immigration. ${ }^{39}$ However, we know the party's leader, Nigel Farage, showed racialized hostility towards Romanians in general. ${ }^{40}$ When this is viewed in conjunction with UKIP's support for wealthy commonwealth members, it reveals what was termed in the Balkan context: 'nesting orientalisms' (a hierarchy of orientalized subjects which need not correspond to dominant geo-historical manifestation of racialized difference). ${ }^{41}$ Furthermore, Farage's comments about a supposed Muslim 'fifth column' existing in Britain, due to 'multiculturalism', illustrates the well-established tradition of using 'multiculturalism' as a proxy for orientalist notions of cultural incompatibility and inferiority. ${ }^{42}$

How UKIP defends multicultural society as a means of recasting state racism can be found elsewhere. As the contours of racialization encompass new (white) migrants, a post-racial discourse on immigration surfaces that enables racialized British citizens to become agents of anti-immigration politics. Racialized ethnic minority Britons have long perceived a complicity between stringent immigration laws and racism. ${ }^{43}$ Yet in recent years this has been confounded by support for hard-line anti-immigration policies amongst a sizable minority of British Asians comparable to the white British population. ${ }^{44}$ In 2013 and 2014, this development was politically expressed by British nationals from the new commonwealth (or those labelled as $n$th generation immigrants such as former UKIP member Sanya-Jeet Thandi) through constituting themselves as advocates of UKIP's anti-immigration. ${ }^{45}$ 
This development was termed UKIP's 'Clause IV' moment - a reference to the moment Labour formally abandoned its socialist objectives of worker ownership. ${ }^{46}$ If we simply dismiss the inclusion of minority anti-immigrant sentiment as mere tokenism aimed at keeping old supporters while gaining new ones, rather than the identitarian sea-change the analogy implies, we miss an important development in how just-in-time citizens have come to express state racism. It marks an unprecedented shift in how racialized British citizens are able to constitute themselves for the first time as generators of state racism, rather than primary recipients.

Consider the UKIP 'carnival' held in Croydon during the run-up to the 2014 European and local elections. The UKIP candidate Winston McKenzie campaigned in front of a steel band, some of whom were initially unaware that they had been hired for a UKIP event. ${ }^{47}$ The choice of music suggested a patronizing representation of ethnic diversity that has been used from 1980s onwards as a symbol of an inclusive multicultural society. However, as anti-UKIP protesters arrived, the black candidate was confronted by charges of racism from those who claimed to be Romanian. ${ }^{48}$ This illustrates a complex situation of multiculture where the institutional racism of the prevailing migration regime, which Derek McGhee argues is supposedly partial to 'more EU (European, White, Christian) entrants', does not always correspond to the bodies that are traditionally associated with enacting or receiving state racism. ${ }^{49}$ This is further exemplified with UKIP's response in 2013 to charges of racism by Lord Heseltine, a Conservative peer and former minister. Amjad Bashir, a UKIP MEP, stated he was more competent than the Conservative peer in using the term since, because of his Pakistani origin, he had experienced racism. Following from this, he called the charges by Heseltine counterproductive to a 'serious debate about immigration'. ${ }^{50}$

Just-in-time citizens' usage of racialized difference as central for justifying the parameters of citizenship, through its supposed insignificance for immigration debates, exemplifes an unforeseen twist in the politics of what Hall termed 'new ethnicities'. ${ }^{51}$ The shift away from a black/white binary in identification and social ascription had previously been viewed as challenging essentialist assumptions of how racialized identities and anti-racist political agendas conjoin. ${ }^{52}$ From the 1980 s onwards, anti-racism became considered more effective if it took into account diverse practices of ethnic self-identification and non-equivalent 'modes of oppression'. ${ }^{53}$ However, UKIP's minorities illustrate McGhee's observation that the host society, which is traditionally equivalent to a white population, has been partially severed through incorporating 'settled communities' as hosts. ${ }^{54}$ Through this seemingly inclusive process, 'contingent insiders' emerge as subject to hierarchies of belonging that can in turn dispense new ways of excluding new arrivals. ${ }^{55}$ Imporantly, UKIP's just-in-time citizens demonstrate how these new agents of state racism were produced on the spur of the moment 
when charges of racism were levelled at UKIP during 2013-14 from across the political spectrum.

Just-in-time citizens' enactment of state racism depends on a novel expression of orientalist citizenship. If, as Bryan Turner notes, orientalist citizenship traditionally operated through a 'system of absences - absent cities, the missing middle class, missing autonomous urban institutions and missing property' which prevented citizenship's emergence, then it follows that the other is considered to have a more fundamental lack. ${ }^{56}$ This remains unstated in orientalist citizenship, but this lack involves the capacity to institute equality by virtue of excluding others. It is through the emergence of racialized just-in-time citizens that we find its articulation transformed to constitute and exclude new immigrants in a post-racial manner.

Hanif Kureishi argues new migrants are constituted as 'the undead, who will invade, colonize and contaminate'. ${ }^{57}$ The contemporary immigrant can be deprived of citizenship without explicit recourse to orientalized and racialized difference. We should not misconstrue this development as another instance of the dominant anti-immigrant crisis of multiculturalism discourse. ${ }^{58}$ Racialized otherness is no longer positioned, in this context, as a mark of citizenship's alterity. The dynamic between just-in-time citizens and zombie immigrants depends on the latter being stripped of all identity except that of an infringement on a 'post-racial' multicultural society.

The trajectory of just-in-time citizens reveals how the role of orientalist citizenship in sustaining state racism is becoming articulated in less traditional terms. The example of UKIP's just-in-time citizens shows that the capacity and ability to exclude others from rights emanates from an anti-essentialist enactment of minority identity politics. Orientalist citizenship was dispensed through inappropriate bodies (e.g., UKIP's minority candidates), as opposed to having permission and exclusion in multicultural society spring from what Ghassan Hage calls the 'white national manager'. ${ }^{5}$

\section{Intercultural Citizens: Make Bradford British}

Aside from recent immigrants being juxtaposed with a 'post-racial' multicultural society, those cast as desirable subjects of multicultural society have become defined as intercultural. This involves a 'descending individualism': establishing divergences from a 'norm' through scientific and disciplinary practices rather than identifying individuals through histories of exceptional ancestry. ${ }^{60}$ The normal and calculable subject of multicultural society was first shaped during the pioneering Canadian experiment in multiculturalism in 1971. ${ }^{61}$ This depended upon joining the 'multicultural assumption', which argued that developing 'self-esteem' in one's previously marginalized identity fosters acceptance by other groups, with the contact hypothesis. ${ }^{62}$ The latter was derived from Gordon Allport's (1954) The Nature of Prejudice, which supposed that the more contact one had with different cultural 
groups, accounting for variables in power, the more likely inter-group tolerance would surface. ${ }^{63}$ While such practices once solely resided under the term 'multiculturalism', they have also come to be understood as interculturalism.

Theoretical differences between multiculturalism and interculturalism are mostly imperceptible. ${ }^{64}$ However, the 'inter' emphasizes one aspect of a predominantly multiculturalist conception of society where the health of society is determined through the quality of interactions that take place across (and within) cultural communities. It is against this backdrop that intercultural citizens emerge as subjects that normalize the terms of cultural relations. This section demonstrates how this transforms expressions of orientalist citizenship to facilitate state racism.

Through envisaging multicultural society as comprised of multiplicity rather than simply majorities and minorities, conditions for a shared dialogic space become ostensibly possible. Bhikhu Parekh argues that intercultural dialogue is essential to permit individuals to 'step outside of their culture... [and] tease out its strengths and weaknesses' ${ }^{65}$ This correspondingly enables them to realize the 'contingency of their culture and relate to it freely... rather than as a fate'. ${ }^{66}$ These dispositions are condensed into the figure of the intercultural citizen.

The Council of Europe's White Paper on Intercultural Dialogue: Living Together as Equals in Dignity published in 2008 stated that an intercultural approach, involving the 'capacity to listen' and 'respectful exchange of views between individuals and groups with different ethnic...backgrounds', is central to a harmonious society ${ }^{67}$ While the intercultural citizen has enough curiosity and ability to learn about others' 'habits and beliefs', this can lead to a position where one speaks for a culture, thereby petrifying its content, meaning, and borders. ${ }^{68}$ This sensitivity towards the otherness of the other is at odds with the traditional figure of the spoken-for orientalized subject. As Ted Cantle argues, emphasizing the intercultural means recognizing how identities are 'chosen and developmental', overlapping, and resistant to ascription. ${ }^{69}$

Yet orientalism is being transformed, rather than overcome, through the intercultural citizen. It is a figure which largely corresponds to a multiculturalist conception of society and can be illustrated through the Channel 4 reality programme Make Bradford British aired in 2012. Like numerous media representations of multicultural society, the documentary caused a brief media frenzy and was later forgotten. It is, however, distinguishable through its promotion of intercultural citizens. The programme mostly concurred with many of the Labour Party's guidelines for community activism such as 'developing resilience' through sharing futures and notions of belongings, while dispelling 'myths' and 'promoting interaction'.$^{70}$ Yet there was one crucial difference. The narrator tacitly participated in the crisis of multiculturalism discourse by stating the programme was in response to Conservative Prime Minister David Cameron's suggestion that 'state multiculturalism' 
promoted 'passive tolerance'. ${ }^{71}$ The programme aimed to 'break away' from tolerance and cohesion discourse. ${ }^{72}$ Instead, it explicitly assumed the mantle of enacting a decentralized, locally envisioned idea of what form desirable multicultural coexistence should assume by finding out how it 'really works' on the ground. ${ }^{73}$

Make Bradford British placed eight people from different classes, ethnicities, and postcodes under the same roof. What the individuals had in common was their labelling as 'failed citizens'. This was defined as those who had failed the Life in the UK citizenship test. The choice of locations within Bradford, predominantly white, Asian, and affluent or deprived areas, supposed that their 'failure' as citizens was related to their lack of everyday contact with different ethnicities. The failed citizen status created an equalized starting line, in regards to British identity, regardless of class or ethnicity. This was possible since Britishness became a quantifiable possession through the citizenship test, which enabled individuals to be collectively judged against a norm. In addition, as participants were said to share a common 'failure' and atypical segregated lifestyle, we were to assume some of the participants' racism was idiosyncratic and exceptional to Britain. Although the common starting point was derived from results of the citizenship test, over the course of the programme, the state that judges their collective failure receded from view. In its place the capacity for non-conflicting social interaction became a measure of citizenship.

An initial viewing of the programme reveals simply a renewed advocacy for contact theory, which makes 'acculturation' and 'adaptation' central for peaceably negotiated cultural difference. ${ }^{74}$ In our context, this became a new way of instilling power relations. As Make Bradford British reached its conclusion, the majority of participants strove for an intercultural position. Even though racist and tolerant beliefs were maintained, participants who held these views were no longer marked as failed citizens. This became evident in the conclusion to the programme when they were brought back to the question of Britishness. This time, however, they were presented as British by virtue of being asked to define their cultural citizenship in subjective terms. Their various narratives were presented to the audience as representative of the plurality of the British national imaginary. The only participant who remained implicitly a failed citizen was the 'South Asian' 'taxi driver'. This was due to his premature departure from the show after his refusal to discuss his patriarchal beliefs. His absence at the end meant that he missed the opportunity given to his fellow participants, now intercultural citizens, to express their Britishness. The unplanned narrative of the programme is symbolic of how intercultural citizens opened spaces for challenging orientalist assumptions. At the same time, intercultural citizens emerged as disciplining subjects who discerned those who qualify as equal citizens. 
Through this particular multiculturalist framing of multicultural society, orientalist citizenship is transformed. A split was created between those who can be normalized as competent for cultural dialogue and individuals perceived as trapped within cultural silos: the 'failed' citizens. However, intercultural citizens became teleological subjects by virtue of eradicating a failed citizen from within their own identity and that of others. A crude state racism, where an 'us' and 'them' are clearly marked, has its dynamic replaced. Intercultural citizens became disciplining subjects that undermined the existence of failed citizens through a non-dichotomous 'us' and 'them'. The unique relation between intercultural and failed citizens may appear to provide an opening for challenges to orientalism. However, intercultural citizens in the context of Make Bradford British reintroduced orientalist citizenship through the normalization of an intercultural position defined against orientalized others who are disbarred from (or refuse to) make this transition.

\section{Anti-civilizational Citizens: Protest through the StWC}

Multicultural society is not only expressed through shaping the legal and cultural conceptions of citizenship. It has also been characterized as the lived experience of multiculture. This can be understood as the diasporic, syncretic, hybrid, and processual performances of difference that can potentially arise to undermine the framing of culture through ethnic absolutisms. ${ }^{75}$ As I previously argued, the multiculture conception of society places greater emphasis on how individuals can be located apart from statist categorizations of ethnicity and singularly quantifiable identities. Logically, it is impossible for multiculture to reinvent orientalist citizenship. When it exceeds being presented as a neutral descriptor of multicultural society, valourizing multiculture intrinsically undermines the genealogies that hold cultures as corresponding to discrete boundaries, bodies, and geographical origins. A brief discussion of the debate between Samuel Huntington and Edward Said reveals how this brand of multiculture can undermine orientalism. This debate provides a starting point from which to highlight changes in orientalist citizenship that incorporate, rather than oppose, progressive articulations of multiculture.

Samuel Huntington argued that humanity is organized into historically durable, hermetically sealed, and culturally incompatible civilizational blocs whose existence becomes threatened when transgression to their fault lines occurs. ${ }^{76}$ Unlike Huntington, who, according to David Cannadine, 'urged accommodation rather than confrontation' between civilizations, Edward Said rejected engaging with the issue of accommodation. ${ }^{77}$ This was due to an initial dispute around civilizational categorization. Said's response to Huntington can be summed up as follows: we live in 'a disorderly reality that won't be pigeonholed or strapped down' ${ }^{78}$ This view derives from the argument that the contemporary sectioning of humanity into 'distinct breeds 
or essences' should be exposed as both a false representation and an effect of power relations. ${ }^{79}$ Instead, he posited culture as necessarily overlapping and appropriating in ways that resist its confinement to identitarian shorthand. ${ }^{80}$ To discern inequity in power relations that transpires through multiculture, Said argued for humanism: 'the agency of human individuality and subjective intuition, rather than [reliance] on received ideas and approved authority'. 81

Said's refusal to challenge orientalist discourse on its own terms, for example by reversing orientalism or promoting tolerance, is a vital means for contesting expressions of orientalism that pervade British media and political discourse. However, orientalism has not remained static in its post-9/11 'Islamophobic' and civilizational articulation. The orientalist War on Terror is partially sustained without relying upon (ideologically obscured) constructs of an 'us' and 'them'. In effect, it sidestepped the symbolic role the Huntington and Said debate has for illustrating our political conjuncture. To illustrate this we can turn to the Stop the War Coalition (StWC) protests. This reveals how an explicit refusal of orientalist terms, through casting oneself as a citizen against notions of civilizational difference, can in fact testify to a transformation in orientalist citizenship.

The StWC protest in 2003 helped organize the largest protest in UK history against the then impending Iraq war. ${ }^{82}$ The StWC prided itself on the diversity of beliefs, nationalities, ethnicities, and ages involved in mobilization. ${ }^{83}$ This diversity extended from the motivation of activism to the differing agendas of the Socialist Workers Party, Campaign for Nuclear Disarmament, and Muslim Association of Britain who were formative of StWC. The diversity of the act - Islamists marching alongside Quakers - embodied the shared demand for human dignity denied through the nascent War on Terror.

The multicultural constitution of the StWC enabled a struggle beyond civilizational dichotomies. Emphasis on a common humanity was vital for contesting the terms of a War on Terror meted out on spectral subjects devoid of humanity, an undead presence that can be repeatedly killed because they are inexhaustible and unindividuated. ${ }^{84} \mathrm{StWC}$ resisted this form of orientalism by deconstructing the situation of humanity in the West. For example, in response to the disproportionate media coverage of the deaths of British soldiers overseas in relation to civilian fatalities, StWC sought to render the latter visible by reading out civilian names in public. ${ }^{85}$ Bringing anonymous others into the sphere of nameable humanity, like the fallen British soldiers, defied the fused national and cultural boundaries of contemporary orientalist citizenship. The unintended function of this critique should also be scrutinized.

Aspects of the worldviews exemplified by Huntington (claiming mastery over an other which can be categorized and governed) and Said (the inability to categorize and govern through orientalism without perpetuating violence) have come to be selectively blended in a War on Terror that governs through 
risk. The effects of orientalism persist through what could be described as 'precautionary risk management'. ${ }^{86}$ This 'displays an insatiable quest for knowledge: profiling populations, surveillance, intelligence, knowledge about catastrophe management, prevention, etc.' ${ }^{87}$ The pre-emptive forms of securitization appear to have legitimated the War on Terror, in particular the 2003 justification for the invasion of Iraq. .8

Less observed is how certain ways of refusing orientalist discourse can in themselves become part of the diffused securitizing strategies of governing in times of risk. Despite the unplanned multicultural diversity and pluralism lauded in the StWC 2003 mobilization, attempts to politicize ethno-religious difference were heavily constrained. This absence was not conspicuous. Some members of the Muslim Association of Britain and the Islamist organization Al-Muhajiroun wanted to emphasize the war as a Muslim plight by excluding non-whites from the mainstream protest. ${ }^{89}$ These individuals were marginalized. ${ }^{90}$ Yet in so far as barring non-secular protesters prevented a specious claim of a war on Muslims, and prevented an inverted clash of civilizations discourse, this sustained practices of state racism. Through protesters being positioned beyond identitarian terms via their shared grievance, the protest assumed a function of vigilance, regulation, and disciplining of public space in case a potential legitimacy for religious protest emerged. According to Salma Yaqoob, the secular nature of the official protest also meant that 'moderate' protesters who offered anti-war rationales on religious grounds could not articulate their grievances as such. ${ }^{91}$

The StWC protests exemplified how defining the protest as an organic expression of multiculture, underpinned by a common objective, potentially offers a path beyond the territorial and population-managerial underpinnings of state racism. At the same time as sustaining anti-civilizational citizens and multiculture, the protests became a site that marked the diffusion of risk-based anti-terrorism. As certain anti-civilizational citizens came to regulate the terms of protest, an unintended expression of orientalist citizenship hardened dividing practices in less perceptible ways than the traditional 'clash of civilizations' discourse.

\section{Conclusion}

Claiming 'society must be defended' is a task undertaken by those who have positioned themselves as part of a legitimate population who can dictate terms for excluding others. This move no longer involves a 'race struggle' where historical discontinuity is introduced into the prevailing notions of the rightful and authentic inhabitants. Instead, state racism emerges to preserve society as irrevocably tethered to the institutions of the state (and thereby constitute society as already 'ours').$^{92}$ This chapter has explored the ways state racism is expressed through attempts to define and defend multicultural society. I uncovered various ways orientalist citizenship has been 
transformed to enable state racism persistence through post-racial, multiculturalist, and multiculture conceptions of society.

The first exploration of orientalist citizenship focused on how it reinforced a conception of multicultural society as post-racial and anti-immigrant. By drawing attention to UKIP's just-in-time citizens, I argued that an antiessentialist severing of a fused racialized identity and support for immigration partially occurred as racialized citizens assumed an orientalist position of excluding others. Second, I showed how Make Bradford British illustrated one way intercultural citizens have defined and defended a multiculturalist conception of society. Of significance was how normalized intercultural citizens were demarcated from failed citizens in non-dichotomous terms to facilitate a more inclusive notion of cultural citizenship. Yet it was precisely this attempt at creating intercultural citizens and failed citizens as occupying dynamic subject positions, rather than mutually exclusive identities, that the intercultural citizen became a disciplining position from which orientalist citizenship could gain a new expression. In a similar vein to UKIP's just-in-time citizens, the normalization of intercultural citizens revealed how transformations in orientalist citizenship enable state racism to persist in situations where biological and culturally defined hierarchies become untenable. Just-in-time and intercultural citizens illustrate positions from which racialized citizens can constitute the legitimate occupants of society and terms of exclusion.

Lastly, I investigated how anti-civilizational citizens emerged through (and depended upon) multiculture. A more thoroughgoing critique of state racism becomes possible through this figure. This is the case since multiculture can potentially erode a genealogy of identity as bearing pure inheritances and valourized statuses, which state racism has historically defined against those who can be killed with impunity. This anti-essentialist challenge to identity was illustrated through StWC protests. However, I demonstrated how this specific instance of deconstructing positions of 'us' and 'them' in the War on Terror also served as an orientalist disciplinary mechanism for normalizing protest as secular and circulating risk-based anti-terrorism.

According to Slavoj Žižek, when individuals become confined to politically acting under the label of cultural difference, heterogeneous struggles for equality become condensed and repressed into a 'post-political' discourse of managing cultural diversity. ${ }^{93}$ The conceptions of multicultural society discussed, and the expressions of citizenship which loosely correspond to each conception, should not be interpreted as yet another general indictment of the 'culturalization of politics'. ${ }^{94}$ This chapter instead analysed orientalist instances of just-in-time, intercultural, and anti-civilizational citizens to illustrate a distinctive issue: how state racism materializes through the co-option of anti-essentialist critique. State racism was shown to depend on these expressions of orientalist citizenship to fulfill its new imperative: multicultural society must be defended. 


\section{Notes}

1 Bhikhu Parekh, "Integrating Minorities," in Race Relations: A Developing Agenda, ed. Tessa Blackstone, Bhikhu Parekh and Peter Sanders (London: Routledge, 1998), 14.

2 David Cameron, PM's speech at Munich Security Conference [online]. Number10. gov. http://www.number10.gov.uk/news/speeches-and-transcripts/2011/02/pms -speech-at-munich-security-conference-60293 (accessed 5 June 2011); Nick Clegg, An Open, Confident Society, The Liberal Democracts, 2011. http://www.libdems .org.uk/latest_news_detail.aspx?title=Nick_Clegg_speech:_An_Open,_Confident _Society\&pPK=25e28e0b-a8e7-4104-ba5e-e860d752c31a. (accessed 4 March 2011); Ken Livingstone, Text of statement by Mayor Ken Livingstone, Financial Times, 2005 http://www.ft.com/cms/s/2/dcdfe116-ef08-11d9-8b10-00000e2511c8.html - axzz3FDu9JDAb. (accessed 3 October 2014).

3 Les Back, Shamser Sinha, and Charlynne Bryan, "New Hierarchies of Belonging," European Journal of Cultural Studies 15, 2 (2012): 679-80.

4 E. F. Isin "Citizenship after Orientalism: Ottoman Citizenship," in Challenges to Citizenship in a Globalizing World: European Questions and Turkish Experiences, eds. F. Keyman and A. Icduygu (London: Routledge, 2005), 31.

5 Ibid.

6 Michel Foucault, "Governmentality," in Power: The Essential Works of Foucault 1954-1984, ed. James D. Faubion (New York: New Press, 2001), 216-17.

7 Michel Foucault, Security, Territory, Population: Lectures at the Collège De France 1977-1978 (Basingstoke: Palgrave Macmillan, 2009), 70.

8 Michel Foucault, Society Must Be Defended (London: Penguin, 2003), 242-3.

9 Ibid., 256.

10 Ibid., 61.

11 Foucault, Security, Territory, Population, 257.

12 Foucault, Society Must Be Defended, 259-63.

13 Luce Irigaray and Michael Marder, "Is 'Democracy' Nothing More Than a Slogan Now?" The New Statesman 2014 (accessed 28 November 2014).

14 Giovanni Sartori, cited in Iker Barbero, "Orientalising Citizenship: The Legitimation of Immigration Regimes in the European Union," Citizenship Studies 16, 5-6 (2012): 759.

15 Engin Isin, "Citizenship after Orientalism: An Unfinished Project," Citizenship Studies 16, 5-6 (2012): 568.

16 Alana Lentin, "Post-Race, Post Politics: The Paradoxical Rise of Culture after Multiculturalism," Ethnic and Racial Studies 5-9 (2012).

17 Varun Uberoi and Tariq Modood, “Who Doesn't Feel British? Divisions over Muslims," Parliamentary Affairs 63, 2 (2010): 304.

18 Maria Sobolewska, "Religious Extremism in Britain and British Muslims: Threatened Citizenship and the Role of Religion," in The New Extremism in the 21st Century, ed. R. Eatwell and M. J. Goodwin (New York: Routledge, 2010), 29.

19 Bhikhu Parekh, "Muslim Alienation and the Obligations of Citizenship," The Times, 7 July 2006.

20 Mahmood Mamdani, Good Muslim, Bad Muslim: America, the Cold War, and the Roots of Terror (New York: Pantheon, 2004).

21 Commission on the Future of Multi-Ethnic Britain (CMEB). The Future of MultiEthnic Britain: The Parekh Report (London: Profile Books).

22 Wendy Brown, Regulating Aversion: Tolerance in an Age of Diversity (Princeton, NJ: Princeton University Press, 2006), 183-4. 
23 Alana Lentin and Gavin Titley, The Crisis of Multiculturalism: Racism in a Neoliberal Age (London: Zed Books, 2011), 187.

24 Sarah Neal et al., "Living Multiculture: Understanding the New Spatial and Social Relations of Ethnicity and Multiculture in England," Environment and Planning C: Government and Policy 31, 2 (2013): 309.

25 Stuart Hall, "Conclusion: The Multi-Cultural Question," in Un/Settled Multiculturalisms, ed. Barnor Hesse (London: Zed Books, 2000), 209.

26 Stuart Hall, The Multicultural Question (Milton Keyenes: Pavis Centre for Social and Cultural Research, The Open University, 2000), 14.

27 William Connolly, "Pluralism, Multiculturalism and the Nation-State: Rethinking the Connections," Journal of Political Ideologies 1, 1 (1996): 60.

28 Ash Amin, "Ethnicity and the Multicultural City: Living with Diversity," Environment and Planning A 34, 6 (2002): 269-70.

29 Elke Winter, Us, Them, and Others (Toronto: University of Toronto Press, 2011), 111.

30 Michel Foucault, Society Must be Defended, 66-7.

31 Ibid.

32 Ann Stoler, Race and the Education of Desire (London: Duke University Press, 1995), 62.

33 CMEB, The Future of Multi-Ethnic Britain: The Parekh Report, 38.

34 Ibid.

35 Ibid.

36 Ibid., 56.

37 Paul Gilroy, "'My Britain Is Fuck All' Zombie Multiculturalism and the Race Politics of Citizenship," Identities 19, 4 (2012): 386.

38 Patrick Wintour and Nicholas Watt, "Ukip Wins European Elections with Ease to Set Off Political Earthquake," The Guardian 2014 http://www.theguardian.com/ politics/2014/may/26/ukip-european-elections-political-earthquake (accessed 2 January 2015).

39 Nigel Farage, Interview with Nigel Farage, Leader of the U.K. Independence Party 2014 http://www.washingtonpost.com/world/interview-with-nigel-farage-leader -of-the-uk-independence-party/2014/05/14/3b2f8c72-f855-47be-b3f 8 -8e7f638ad3a6_story.html (accessed 30 May 2014).

40 BBC, Nigel Farage Defends Romanian Comments Amid Racism Claims. BBC 2014 http://www.bbc.co.uk/news/uk-politics-27474099 (accessed 29 May 2014).

41 Milica Bakic-Hayden, "Nesting Orientalisms: The Case of Former Yugoslavia," Slavic Review 54, 4 (1995): 918.

42 Farage cited in M. Holehouse, "Nigel Farage Blames Paris Attack on 'Rather Gross Policy of Multi-Culturalism,'” The Telegraph 2015 http://www.telegraph.co.uk/ news/politics/nick-clegg/11332461/Nigel-Farage-blames-Paris-attack-on-rather -gross-policy-of-multi-culturalism.html (accessed 9 January 2015).

43 Shamit Saggar, "Immigration and the Politics of Public Opinion," The Political Quarterly 74 (2003): 178-94.

44 Nick Lowles and Aron Painter, "Fear and Hope: The New Politics of Identity," Searchlight Educational Trust 2012 http://www.fearandhope.org.uk/project-report/ themes (accessed 13 July 2013).

45 Sarfraz Manzoor, "The New Faces of Ukip," The Times 2013 http://www.thetimes .co.uk/tto/magazine/article3938636.ece (accessed 3 January 2014).

46 A. Singh, "Why Are Ethnic Minorities Supporting Ukip?" Independent 2014 http://www.independent.co.uk/voices/why-are-ethnic-minorities-supporting -ukip-9347369.html (accessed 19 May 2014). 
47 Georgia Graham and Christopher Hope, "Nigel Farage Feels Too 'Unsafe' to Attend His Own 'Ukip Carnival,'” The Telegraph 2014 http://www.telegraph.co.uk/news/ politics/ukip/10844087/Nigel-Farage-feels-too-unsafe-to-attend-his-own-Ukipcarnival.html (accessed 3 January 2015).

48 Gareth Davies, "Nigel Farage Fails to Show as Ukip 'Carnival' Ends with Winston Mckenzie Calling Croydon an 'Absolute Dump,'” Crydon Advertiser 2014 http:// www.croydonadvertiser.co.uk/Nigel-Farage-fails-Ukip-carnival-ends-Winston/ story-21115536-detail/story.html (accessed 12 June 2014).

49 Derek McGhee, "The Paths to Citizenship: A Critical Examination of Immigration Policy in Britain since 2001," Patterns of Prejudice 43, 1 (2009): 53-54.

50 BBC, "Ukip Is Not a Racist Party, Lord Heseltine Told," BBC 2013 http://www.bbc .co.uk/news/uk-politics-24385139 (accessed 16 June 2014).

51 S. Hall, "New Ethnicities," in 'Race', Culture and Difference, eds. J. Donald and A. Rattansi (London: Sage, 1992).

52 Ibid.

53 T. Modood, "Difference, 'Multi' and Equality," in The Plural States of Recognition, ed. Michel Seymour (Basingstoke, UK: Palgrave Macmillan, 2010), 155.

54 Derek McGhee, "Getting 'Host' Communities on Board: Finding the Balance between 'Managed Migration' and 'Managed Settlement' in Community Cohesion Strategies," Journal of Ethnic \& Migration Studies 32, 1 (2006): 122-3.

55 Les Back, Shamser Sinha, and Charlynne Bryan, "New Hierarchies of Belonging," European Journal of Cultural Studies 15, 2 (2012): 140.

56 Bryan S. Turner, Orientalism, Postmodernism \& Globalism (London: Routledge, 1994).

57 Hanif Kureishi, "The Migrant Has No Face, Status or Story," The Guardian 2014 http://www.theguardian.com/books/2014/may/30/hanif-kureishi-migrant -immigration-1 (accessed 30 May 2014).

58 Alana Lentin and Gavin Titley, The Crisis of Multiculturalism, 2.

59 Ghassan Hage, White Nation: Fantasies of White Supremacy in Multicultural Society (London: Routledge, 2000), 132-3.

60 Foucault cited in John O'Neill, "The Disciplinary Society: From Weber to Foucault," The British Journal of Sociology 37, 1 (1986): 53.

61 Pierre Trudeau, Announcement of Implementation of Policy of Multiculturalism within Bilingual Framework, Heritage Community Foundation 1971 http://www .abheritage.ca/albertans/speeches/trudeau.html (accessed 25 June 2011).

62 John W. Berry, Rudolf Kalin, and Donald M. Taylor, Multiculturalism and Ethnic Attitudes in Canada (Ottawa: Minister of Supply and Services, 1977).

63 Thomas F. Pettigrew, "Intergroup Contact Theory," Annual Review of Psychology 49 (February 1998): 66-9.

64 Nasar Meer and Tariq Modood, "How Does Interculturalism Contrast with Multiculturalism?," Journal of Intercultural Studies 33, 2 (2012): 175-96.

65 Bhikhu Parekh, Rethinking Multiculturalism: Cultural Diversity and Political Theory (Basingstoke, UK: Palgrave Macmillan, 2000), 167.

66 Ibid.

67 Council of Europe, White Paper on Intercultural Dialogue "Living Together as Equals in Dignity," Council of Europe 2008 bit.ly/MRx6jshttp://www.coe.int/t/dg4/ intercultural/source/white paper_final_revised_en.pdf, 17 (accessed 6 November 2013).

68 Will Kymlicka, "Multicultural States and Intercultural Citizens," Theory and Research in Education 1, 2 (2003): 158-60. 
69 Ted Cantle, "Interculturalism: For the Era of Globalisation, Cohesion and Diversity," Political Insight (December 2012): 40.

70 Jo Broadwood and Nicola Sugden, Building Cohesive Communities: What Frontline Staff and Community Activists Need to Know (London: Department for Communities and Local Government, 2009), 6-12.

71 Laurie Trott, Lessons to Learn, Channel 42012 http://www.channel4.com/ programmes/make-bradford-british/articles/lessons-to-learn (accessed 2 March 2012).

72 Ibid.

73 Channel 4, Make Bradford British (2012).

74 John W. Berry, "Immigration, Acculturation, and Adaptation," Applied Pyschology: An International Review 46, 1 (1997): 6-7.

75 Paul Gilroy, The Black Atlantic: Modernity and Double Conciousness (London: Verso, 1992); J. N. Pieterse, Ethnicities and Global Multiculture: Pants for an Octopus (Plymouth: Rowman \& Littlefield, 2007).

76 Samuel Huntington, The Clash of Civilizations and the Remaking of the World Order (New York: Simon \& Schuster, 1996).

77 David Cannadine, The Undivided Past: History Beyond Our Differences (London: Allen Lane, 2013), 253.

78 Edward W. Said, "The Clash of Ignorance," The Nation 2001 http://www .unipa.it/ michele.cometa/Said_The Clash of Ignorance.pdf (accessed 7 August 2013).

79 Edward W. Said, Orientalism (London: Penguin, 2003[1978]), 348-9.

80 Said, Orientalism, xxii.

81 Ibid.

82 BBC, “'Million' March against Iraq War,'” BBC 2003 http://news.bbc.co.uk/1/hi/ uk/2765041.stm. (accessed 10 December 2011).

83 Lindsey German, War and Resistance: Moving on Up 2002 http://www .socialistreview.org.uk/article.php?articlenumber=8187 (accessed 5 August 2013).

84 Judith Butler, Precarious Life: The Powers of Mourning and Violence (London: Verso, 2004), 33-4.

85 StWC, Tyneside Stop the War Coalition Reads the Names of the Dead at Newcastle Monument. North East Stop the War 2009 http://www.northeaststopwar.org.uk/ archive/manch08/100death.htm (accessed 2 August 2013).

86 Claudia Aradau and Rens Van Munster, "Governing Terrorism through Risk: Taking Precautions, (Un)Knowing the Future," European Journal of International Relations 13, (2007): 104.

87 Ibid., 91.

88 Ibid., 109.

89 Richard Phillips, "Standing Together: The Muslim Association of Britain and the Anti-War Movement," Race \& Class 50, 2 (2008): 101-13.

90 Andrew Murray and Lindsey German, Stop the War: The Story of Britain's Biggest Mass Movement (London: Bookmark Publications, 2005), 61.

91 Yahya Birt, "Islamophobia in the Construction of British Muslim Identity Politics," in Muslims in Britain: Race, Place and Identities, ed. Peter Hopkins and Richard Gale (Edinburgh, UK: Edinburgh University Press, 2009).

92 Foucault, Society Must be Defended.

93 Slavoj Žižek, "Tolerance as an Ideological Category," Critical Inquiry 34 (2008): 660.

94 Ibid. 
Davies, Gareth. "Nigel Farage Fails to Show as Ukip 'Carnival' Ends with Winston Mckenzie Calling Croydon an 'Absolute Dump'," Crydon Advertiser (2014) http:// www.croydonadvertiser.co.uk/Nigel-Farage-fails-Ukip-carnival-ends-Winston/ story-21115536-detail/story.html (accessed 12 June 2014].

Farage, Nigel. "Interview with Nigel Farage, Leader of the U.K. Independence Party 2014" http://www.washingtonpost.com/world/interview-with-nigel-farage-leader -of-the-uk-independence-party/2014/05/14/3b2f8c 72 -f855-47be-b3f 8 -8e7f638ad3a6_story.html (accessed 30 May 2014).

Foucault, Michel. "Governmentality," in Power: The Essential Works of Foucault 19541984, ed. James D. Faubion (New York: New Press, 2001).

Foucault, Michel. Security, Territory, Population: Lectures at the Collège De France 19771978 (Basingstoke: Palgrave Macmillan, 2009).

Foucault, Michel. Society Must Be Defended (London: Penguin, 2003).

German, Lindsey. "War and Resistance: Moving on Up 2002" http://www.socialistreview .org.uk/article.php?articlenumber=8187 (accessed 5 August 2013).

Gilroy, Paul. The Black Atlantic: Modernity and Double Conciousness (London: Verso, 1992).

Gilroy, Paul. "'My Britain Is Fuck All' Zombie Multiculturalism and the Race Politics of Citizenship," Identities 19, 4 (2012): 380-97.

Graham, Georgia, and Christopher Hope. "Nigel Farage Feels Too 'Unsafe' to Attend His Own 'Ukip Carnival'," The Telegraph (2014) http://www.telegraph.co.uk/news/ politics/ukip/10844087/Nigel-Farage-feels-too-unsafe-to-attend-his-own-Ukip-carnival.html (accessed 03 January 2015).

Hage, Ghassan. White Nation:Fantasies of White Supremacy in Multicultural Society (London: Routledge, 2000).

Hall, Stuart. "Conclusion: The Multi-Cultural Question," in Un/Settled Multiculturalisms, ed. Barnor Hesse (London: Zed Books, 2000).

Hall, Stuart, "Cultural Identity and Diaspora," Identity: Community, culture, difference 2 (1990): 222-37.

Hall, Stuart. "The Meaning of New Times," in Stuart Hall: Critical Dialogues in Cultural Studies, eds. D. Morley and K. Chen (London: Routledge, 1996[1989]).

Hall, Stuart. The Multicultural Question (Milton Keyenes: Pavis Centre for Social and Cultural Research, The Open University, 2000).

Hall, Stuart. "New Ethnicities," in 'Race', Culture and Difference, eds. James Donald and Ali Rattansi (London: Sage, 1992).

Hall, Stuart, and Les Back, "At Home and Not at Home: Stuart Hall in Conversation with Les Back," Cultural Studies 23, 4 (2009): 657-88.

Hesse, Barnor. "Diasporicity: Black Britain's Post-Colonial Formations," in Un/Settled Multiculturalisms, ed. Barnor Hesse (London: Zed Books, 2000).

Holehouse, Matthew. "Nigel Farage Blames Paris Attack on 'Rather Gross Policy of Multi-Culturalism', " The Telegraph (2015) http://www.telegraph.co.uk/news/ politics/nick-clegg/11332461/Nigel-Farage-blames-Paris-attack-on-rather-gross -policy-of-multi-culturalism.html (accessed 9 January 2015).

Huntington, Samuel. The Clash of Civilizations and the Remaking of the World Order (New York: Simon \& Schuster, 1996).

Irigaray, Luce, and Michael Marder. "Is 'Democracy' Nothing More Than a Slogan Now?," The New Statesman (2014) (accessed 28 November 2014).

Isin, Engin F. "Citizenship after Orientalism: Ottoman Citizenship," in Challenges to Citizenship in a Globalizing World: European Questions and Turkish Experiences, eds. F. Keyman and A. Icduygu (London: Routledge, 2005). 